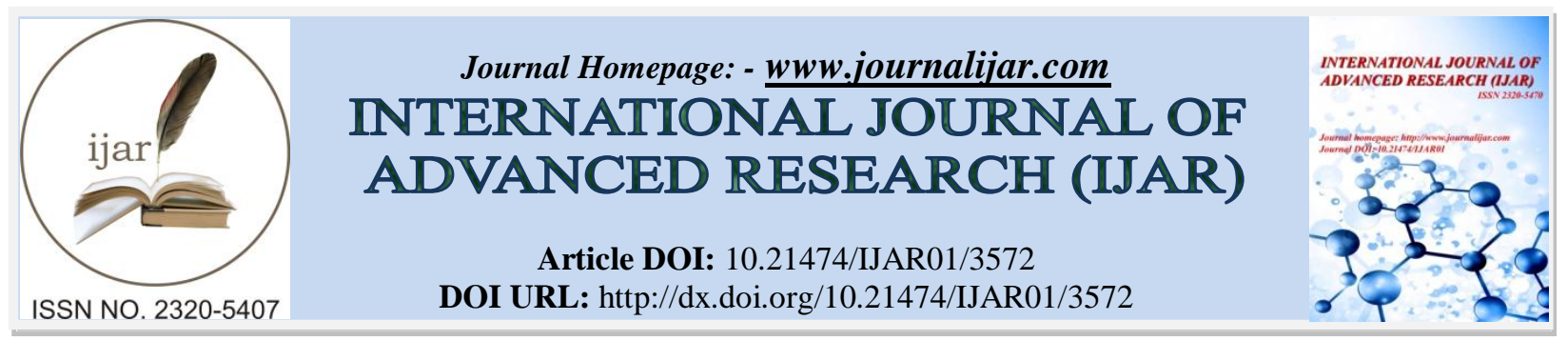

RESEARCH ARTICLE

\title{
SYNTHESIS AND HERBICIDAL ACTIVITIES OF PYRAZOLE- 4-CARBOHYDRAZIDE DERIVATIVES.
}

Shailesh Prabhakar Ghag and Chitra Rajesh Kamath.

Department of Chemistry, K. J. Somaiya College of Science \& Commerce, Vidyanagar, Vidyavihar (E), Mumbai 77.

\section{Manuscript Info}

\section{Manuscript History}

Received: 03 January 2017

Final Accepted: 08 February 2017

Published: March 2017

Key words:-

Pyrazole Carbohydrazide,

Chloro(aminopyrazoly) Ketones

derivatives, Herbicidal Activity.

\section{Abstract}

In order to obtain new chloro(aminopyrazoly)ketone compounds with good herbicidal activity, a series of 5-Chloro-3-methyl-1-phenyl-1H pyrazole-4-carbohydrazide derivatives were designed and synthesized using a series of relational synthons. Their structures were determined by IR, $1 \mathrm{H}$ NMR, and elemental analyses. These compounds were screened for Herbicidal activities against Barnyard grass and Rape seed.

\section{Scheme 1:-}



Where $\mathrm{R}_{1}=\mathrm{CH}_{3}, \mathrm{H} ; \mathrm{R}_{2}=\mathrm{COOC}_{2} \mathrm{H}_{5}, \mathrm{CONHNH}_{2}, \mathrm{CN}, \mathrm{H} ; \mathrm{R}_{3}=\mathrm{NH}_{2}, \mathrm{OH}$

\section{Introduction:-}

Pyrazole type herbicidal are those compounds which having a low phytotoxicity, exhibiting excellent herbicidal activity at lower dosages than known analogous herbicidal. As reported, many 4-carbonyl pyrazole derivatives classified as the inhibitors of 4-4-hydroxyphenol-pyruvate dioxygenase (4-HPPD) displayed excellent herbicidal activities, such as pyrazolynate 1, pyrazoxyfen $\mathbf{2}$ and benzofenap 3 (Figure 1). 4-HPPD inhibitor are a class of herbicides that prevent plants by blocking 4-Hydroxyphenyl pyruvate dioxygenase, an enzyme in plants that breaks down the amino acid, tyrosine into components that are used by plants to create other molecules that plants need. This process of breakdown, or catabolism, and making new molecules from the results, or biosynthesis, is something all living things do ${ }^{1}$.

Corresponding Author:- Shailesh Prabhakar Ghag.

Address:- Department of Chemistry, K. J. Somaiya College of Science \& Commerce, Vidyanagar, Vidyavihar (E), Mumbai - 77. 
HPPD inhibitors were first brought to market in 1980, although their mechanism of action was not understood until the late 1990s. They were originally used primarily in Japan in rice production, but since the late 1990s have been used in Europe and North America for corn, soybeans, and cereals, and since the 2000s have become more important as weeds have become resistant to glyphosate and other herbicides. Among these Benzofenap is a Pyrazole herbicide first synthesized in 1981 by Mitsubishi Petrochemical Company ${ }^{2}$.It is a translocated, selective, root and shoots absorbed herbicide used mainly for broad-leaved water weed control in Rice. Pyrazolynate, an herbicide belonging to the group unclassified is used for controlling weeds. Several Pyrazolynate also has a high activity on rice weeds ${ }^{3}$.Pyrazoxyfen is a benzoyl pyrazole herbicides, it is used pre or post emergence after transplanting in paddy rice to control annul and perennial weeds ${ }^{4}$. It can be used to direct seeded rice.

By comparisons with other 4-hydroxyphenol-pyruvate dioxygenase (4-HPPD) inhibitors, it was concluded that their main pharmacophore was 5-hydroxyl-4-benzoyl pyrazole. It was also noticed that amino group possessed a similar capability of forming complex compounds with hydroxyl group, and according to the bioisosterism theory, both pyrazole ring and benzene ring were ring equivalents. Also it had chloro group at $5^{\text {th }}$ position in main pyrazole moiety. However, the pyrazole derivatives containing two pyrazole rings used as herbicide have been rarely reported. In order to find valuable lead compounds with high herbicidal activity, a series of the title compounds 67(Figure 1) were designed and synthesized.



Figure 1.Chemical Structure 6-7 


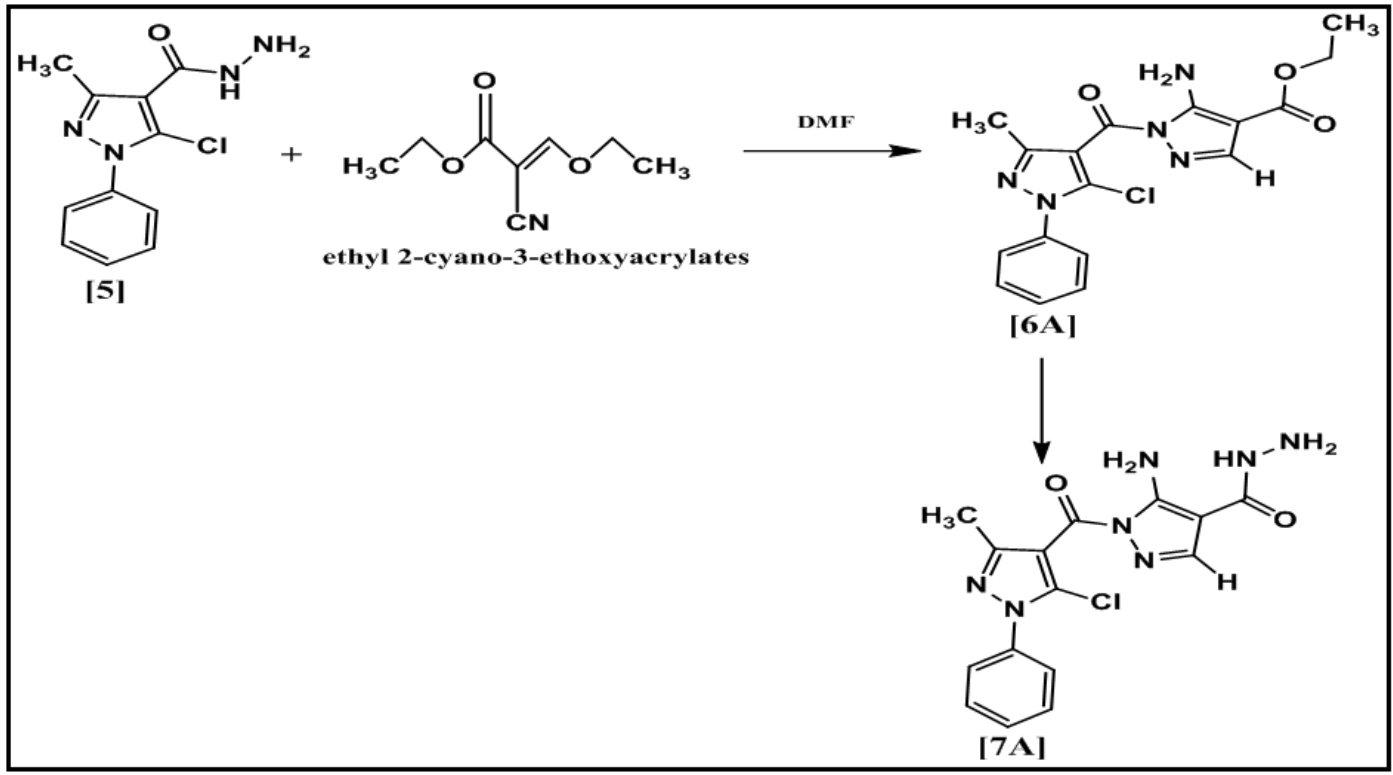

Schemes 1.

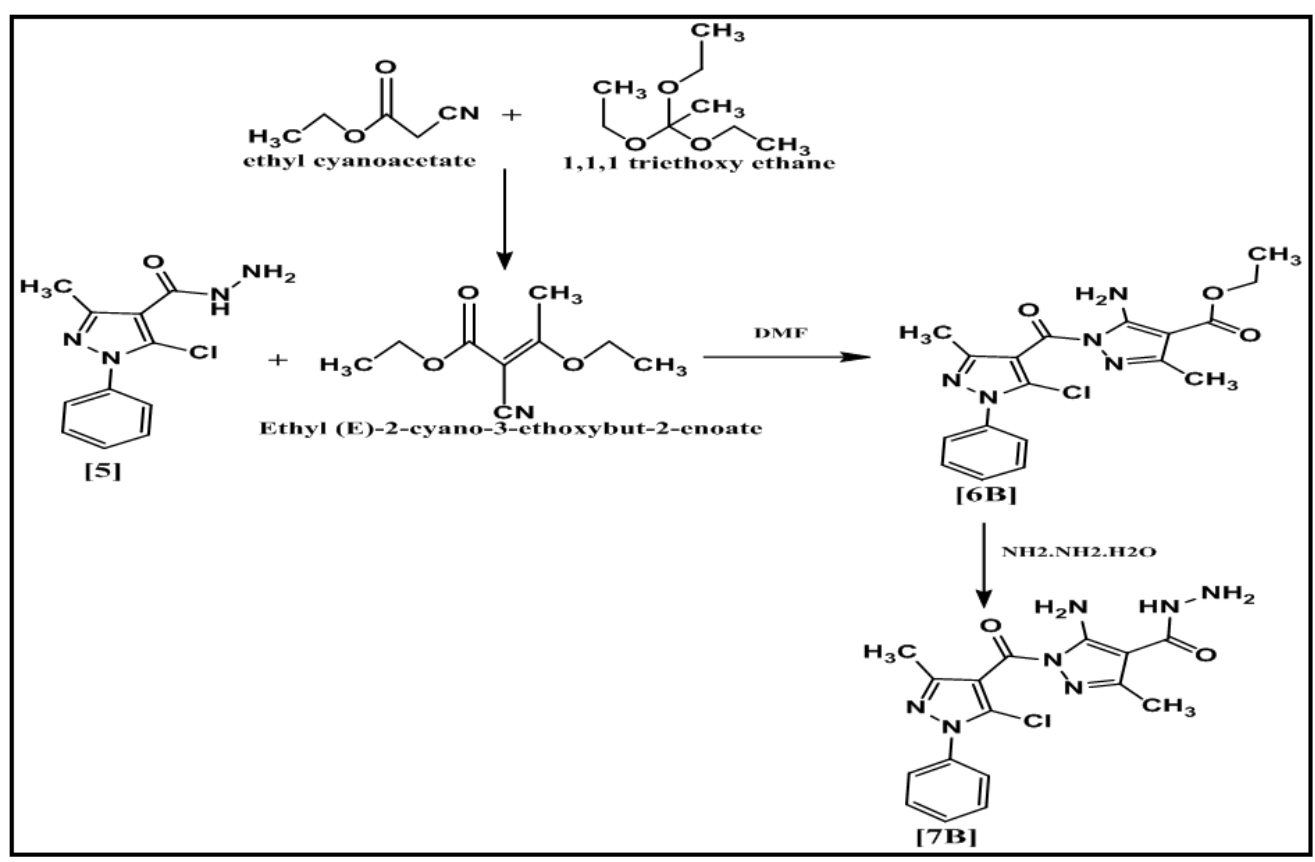

Schemes 2.

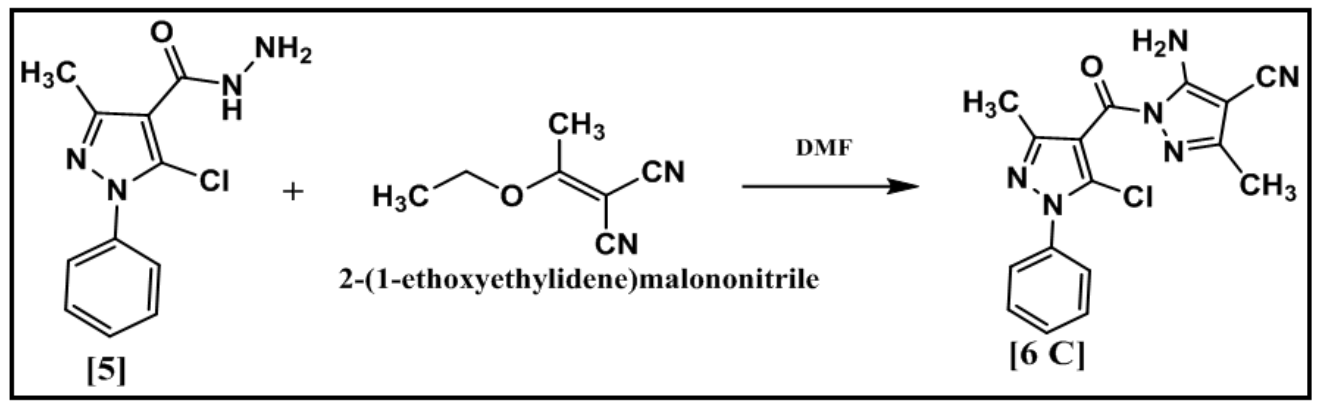

Scheme 3. 


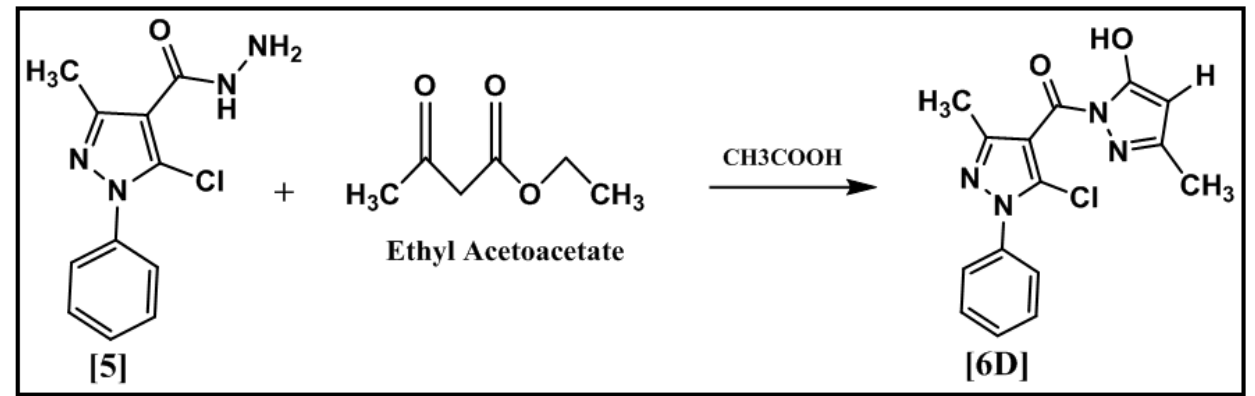

Material and Method:-

Scheme 4.

\section{Synthesis:-}

5-Chloro-3-methyl-1-phenyl-1H-pyrazole-4-carbohydrazide was prepared as per the procedure described in our research paper ${ }^{5}$

The title compounds were synthesized according to Scheme 1-4 by in a parallel synthesis fashion, by which a number of 5-Amino compounds with various substitutions and 5-Hydroxyl compound are produced. In First, ethyl 2-cyano-3-ethoxyacrylates were reacted with 5-Chloro-3-methyl-1-phenyl- $1 \mathrm{H}$-pyrazole-4-carbohydrazide [5] to obtained Ethyl-5-amino-1-(5-chloro-3-methyl-1-phenyl-1 $H$-pyrazole-4-carbonyl)-1 $H$-pyrazole-4-carboxylate[6A], then $[6 \mathrm{~A}]$ was transformed to its hydrazine derivatives $[6 \mathrm{~B}]$.

In second scheme, ethyl cyanoacetate reacted with 1,1,1 triethoxy ethane to obtained Ethyl (E)-2-cyano-3ethoxybut-2-enoate. This is reacted with 5-Chloro-3-methyl-1-phenyl- $1 \mathrm{H}$-pyrazole-4-carbohydrazide [5] to obtain Ethyl-5-amino-1-(5-chloro-3-methyl-1-phenyl-1H-pyrazole-4-carbonyl)-3-methyl-1 $\mathrm{H}$-pyrazole-4-carboxylate

$[7 \mathrm{~A}]$.Then $[7 \mathrm{~A}]$ was transformed to its hydrazine derivatives [7B].

In third scheme 2-(1-ethoxyethylidene)malononitrile was reacted with 5-Chloro-3-methyl-1-phenyl-1H-pyrazole-4carbohydrazide [5] to obtained 5-Amino-1-(5-chloro-3-methyl-1-phenyl-1 $\mathrm{H}$-pyrazole-4-carbonyl)-3-methyl- $\mathrm{H}$ pyrazole-4-carbonitrile [6C].

In forth scheme Ethyl acetoacetate was reacted with 5-Chloro-3-methyl-1-phenyl-1 $H$-pyrazole-4-carbohydrazide [5] to obtained (5-Chloro-3-methyl-1-phenyl-1 $H$-pyrazol-4-yl)(5-hydroxy-3,4-dimethyl-1H-pyrazol-1-yl) methanone [6D].All compounds are characterized by $1 \mathrm{H}$ NMR and FTIR analysis.

\section{Herbicidal activity:-}

These compounds were screened for herbicidal activities against rape and Barnyard grass (Table 1). The results showed that, when R2 was 4-carbohydrazide group [6B \& 7B], compounds always possessed better herbicidal activities against barnyard grass rather than ester, cyano and hydroxyl group at $100 \mathrm{ug} / \mathrm{mL}$; All the synthesized compounds showing non-inhibitory activity against Rape root.

Table 1:- Structure and herbicidal activity of targeted compounds.

\begin{tabular}{|c|c|c|c|c|c|c|c|c|}
\hline $\begin{array}{c}\text { Sample } \\
\text { No. }\end{array}$ & Comp. & $\mathbf{R}_{\mathbf{1}}$ & $\mathbf{R}_{\mathbf{2}}$ & $\mathbf{R}_{\mathbf{3}}$ & $\mathbf{M P}\left({ }^{\circ} \mathbf{C}\right)$ & $\begin{array}{c}\text { Yield } \\
\mathbf{\%}\end{array}$ & $\begin{array}{c}\text { Rape root Test } \\
(\mathbf{c m})\end{array}$ & $\begin{array}{c}\text { Barnyard grass } \\
\text { cup test (cm) }\end{array}$ \\
\hline & & & & & & & $\mathbf{1 0 0} \boldsymbol{\mu \mathbf { g } / \mathbf { m L }}$ & $\mathbf{1 0 0} \boldsymbol{\mu g} / \mathbf{m L}$ \\
\hline 1 & Water & & & & & & $\mathbf{6}$ & $\mathbf{5 . 7}$ \\
\hline 2 & Blank & & & & & & $\mathbf{5 . 8}$ & $\mathbf{5 . 0}$ \\
\hline $\mathrm{A}$ & $6 \mathrm{~A}$ & $-\mathrm{H}$ & $-\mathrm{COOC}_{2} \mathrm{H}_{5}$ & $-\mathrm{NH}_{2}$ & $236-238$ & 54 & 3.75 & 1.25 \\
\hline $\mathrm{B}$ & $6 \mathrm{~B}$ & $-\mathrm{H}$ & $-\mathrm{CONHNH}_{2}$ & $-\mathrm{NH}_{2}$ & $289-292$ & 60 & 4.0 & 0.75 \\
\hline $\mathrm{C}$ & $7 \mathrm{~A}$ & $-\mathrm{CH}_{3}$ & $-\mathrm{COOC}_{2} \mathrm{H}_{5}$ & $-\mathrm{NH}_{2}$ & $225-228$ & 58 & 3.80 & 2.25 \\
\hline $\mathrm{D}$ & $7 \mathrm{~B}$ & $-\mathrm{CH}_{3}$ & $-\mathrm{CONHNH}_{2}$ & $-\mathrm{NH}_{2}$ & $282-285$ & 60 & 4.0 & 0.45 \\
\hline $\mathrm{E}$ & $6 \mathrm{C}$ & $-\mathrm{CH}_{3}$ & $-\mathrm{CN}$ & $-\mathrm{NH}_{2}$ & $285-288$ & 50 & 3.65 & 2.0 \\
\hline F & $6 \mathrm{D}$ & $-\mathrm{CH}_{3}$ & $-\mathrm{H}$ & $-\mathrm{OH}$ & $250-254$ & 45 & 3.77 & 1.25 \\
\hline
\end{tabular}


Figure 2:- Herbicidal Activity of compounds containing carbohydrazide group at $4^{\text {th }}$ position [6B \& 7B] on
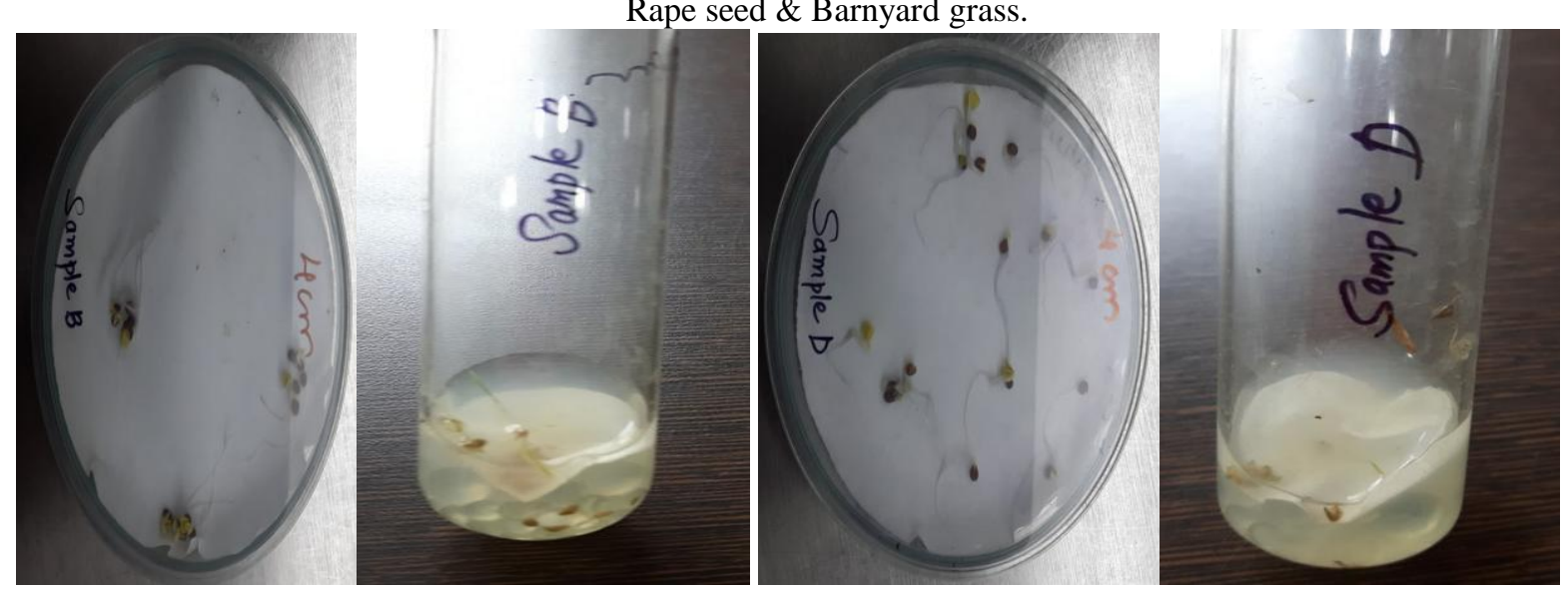

\section{Experimental:-}

General Methods:-

Melting points were determined in open capillary on an electrically heated block are uncorrected. IR ( $\mathrm{KBr}$ ) spectra were recorded on Perkin Elmer FTIR and only noteworthy absorption levels $\left(\mathrm{cm}^{-1}\right)$ are listed. PMR spectra on Varian $300 \mathrm{MHz}$ and AMX-400 Bruker spectrophotometer using TMS as an internal standard and chemicals shifts measured in $\delta(\mathrm{ppm})$. The required 3-Methyl-1-phenyl-2-pyrazolin-5-one was prepared according to Vogel's procedure 6 . Diazomethane required for the methylation of acid was prepared according to Organic synthesis method $^{7}$.

5-Chloro-3-methyl-1-phenyl-1H-pyrazole-4-carbaldehyd [2] was prepared under Vilsmeier conditions ${ }^{8,9}$ from 3Methyl-1-phenyl-2-pyrazolin-5-one [1] in which chlorination of C-5 occurs in addition to the expected formylation. This 4-carboxaldehyde is than oxidized with Potassium paramagnet ${ }^{10}$ to gives 5-Chloro-3-methyl-1-phenyl- $1 \mathrm{H}$ pyrazole-4-carboxylic Acid [3]. This acid is then methylated by diazomethane in dry ether to give 5-Chloro-3methyl-1-phenyl-1H-pyrazole-4-carboxyllic acid methyl ester [4].The methyl ester is then treated with to hydrazine hydrate to give 5-Chloro-3-methyl-1-phenyl-1 $H$-pyrazole-4-hydrazone [5].

TLC was used to assess the reactions and the purity of the synthesized compounds. All the compounds gave satisfactory elemental analysis.

\section{3-Methyl-1-phenyl-2-pyrazolin-5-one [1]:-}

$50 \mathrm{gm}(49 \mathrm{~mL}, 0.384$ mole) of redistilled ethyl acetoacetate and $40 \mathrm{gm}(36.5 \mathrm{~mL}, 0.37 \mathrm{~mole})$ of phenyl hydrazine were mixed together in a large evaporating dish. The mixture was heated on a boiling water bath in the fume cupboard for about 2 hours and stirred from time to time with glass rod. The heavy reddish syrup was allowed to cool somewhat, about $100 \mathrm{~mL}$. of ether was added to it and the mixture was stirred vigorously. The syrup, which was insoluble in ether, solidified within 15 minutes. The solid was filtered at the pump and washed thoroughly with ether to remove colored impurities. It was recrystallised from hot water to give 3-methyl-1-phenyl-2-pyrazolin-5one.

\section{Chloro-3-methyl-1-phenyl-1 $\boldsymbol{H}$-pyrazole-4-carbaldehyde [2]:-}

For the preparation of 5-Chloro-3-methyl-1-phenyl-1 $\mathrm{H}$-pyrazole-4-carbaldehyde, $\mathrm{POCl}_{3}(0.35$ mole, $32.0 \mathrm{~mL}$.) was added to ice-cold dimethyl formamide $(0.16$ mole, $12.0 \mathrm{~mL}$.). To this mixture 3-Methyl-1-phenyl-2-pyrazolin-5-one [1] $(0.05$ mole, $8.1 \mathrm{gm})$ was added and the mixture was heated under reflux for $1.0 \mathrm{hrs}$. After cooling the reaction mixture was poured into ice-cold water $(300 \mathrm{~mL})$. The solid precipitated was collected by filtration, washed with cold water, dried and recrystallised from ethanol to give pale yellow crystal of 5-Chloro-3-methyl-1-phenyl-1 $\mathrm{H}$ pyrazole-4-carbaldehyde. Yield (90\%), mp: $145-148^{\circ} \mathrm{C}$.

\section{Chloro-3-methyl-1-phenyl-1H-pyrazole-4-carboxylic Acid [3]:-}

In three $500 \mathrm{~mL}$ flask, 5-Chloro-3-methyl-1-phenyl-1 $\mathrm{H}$-pyrazole-4-carbaldehyde [2] $0.05 \mathrm{~mol}$ and $100 \mathrm{~mL}$ of water was slowly added dropwise $0.075 \mathrm{~mol} \mathrm{KMnO} 4$ in $200 \mathrm{~mL}$ aqueous oxidation. Dropping was completed, the 
temperature was raised to $70-80^{\circ} \mathrm{C}$ reactor $8 \mathrm{~h}$. Adjusting the $\mathrm{pH}$ of the reaction solution was made alkaline with $10 \%$ Barium Hydroxide solution was slowly cooled, insoluble's were removed by filtration, and the filtrate was acidified with concentrated hydrochloric acid, the precipitated white solid was suction filtered, washing and drying, a white solid; Yield: Yield- (70.0\%) mp: $230{ }^{\circ} \mathrm{C}$.

Chloro-3-methyl-1-phenyl-1H-pyrazole-4-carboxylic Acid Methyl ester [4]:-

2.365 gm (0.01 mole) of 5-Chloro-3-methyl-1-phenyl-1 $H$-pyrazole-4-carboxylic acid [3] was dissolved in $25 \mathrm{~mL}$ of ether. The solution was cooled to $0^{\circ} \mathrm{c}$, with proper precaution excess diazomethane solution was added. As the reaction continued nitrogen generated in the reaction solution bubbled out. The reaction mass was kept in refrigerator overnight. Excess diazomethane was distilled out. The solid precipitate of 5-Chloro-3-methyl-1-phenyl$1 \mathrm{H}$-pyrazole-4-carboxylic acid methyl ester was recrystallized in ethanol. Yield- $75 \% \mathrm{mp}: 68{ }^{\circ} \mathrm{C}$.

Chloro-3-methyl-1-phenyl-1 $\boldsymbol{H}$-pyrazole-4-carboxylic acid hydrazide [5]:-

2.0 gm of 5-Chloro-3-methyl-1-phenyl-1 H-pyrazole-4-carboxylic acid methyl ester [4] was kept overnight under reflux in $10.0 \mathrm{~mL}$ of hydrazine hydrate. $25.0 \mathrm{~mL}$ of chloroform was added to the reaction mass and the hydrazine hydrate layer was separated. The chloroform layer was washed three times with water. The chloroform layer was dried on anhydrous sodium sulfate. The chloroform was evaporated to get solid precipitate of 5-Chloro-3-methyl-1phenyl-1 $H$-pyrazole-4-carboxylic acid hydrazide. It was recrystallized in ethanol. Yield- $(60.0 \%) \mathrm{mp}: 172-175^{\circ} \mathrm{C}$.

General procedure for the synthesis of title compounds [6A, 7A \& 6C]:-

To a solution of intermediate [5] (5.0 mmol) in 15mL DMF is added Cyano compound (5.5 mmol). The mixture is refluxed for $8 \mathrm{~h}$ and cooled to room temperature, then poured into $30 \mathrm{~mL}$ water. The precipitate is collected by filtration and a white solid is obtained. The solid is purified by Column Purification. Desired products [6 A, 7 A \& 6C] are obtained.

Procedure for the synthesis of title compounds [6D]:-

To a solution of intermediate [5] $(5.0 \mathrm{mmol})$ in $15 \mathrm{~mL}$ Acetic Acid is added Ethyl acetoacetate (5.5 mmol). The mixture is refluxed for $10 \mathrm{~h}$ and cooled to room temperature, then poured into $30 \mathrm{~mL}$ water. The precipitate is collected by filtration and a white solid is obtained. The solid is purified by Column Purification. Desired product [6D] is obtained.

General Procedure for the Reaction of 5-Amino-1H-pyrazole-4-carbohydrazide [6B \&7B]:-

A suspension of pyrazole derivatives [6A or $7 \mathrm{~A}](0.05 \mathrm{~mol})$ in $14.7 \mathrm{~mL} 85 \%$ hydrazine hydrate is heated at $105^{\circ}$ for $6 \mathrm{~h}$. Then the solution is evaporated under vacuum and cooled to room temperature. The residue is filtrated; washed with $25 \mathrm{~mL}$ diethyl ether three times. White crystalline solids [6B or 7B] are obtained.

Ethyl-5-amino-1-(5-chloro-3-methyl-1-phenyl-1H-pyrazole-4-carbonyl)-1H-pyrazole-4-carboxylate [6A]:This compound is obtained as colorless white crystals (alcohol), yield $54 \%$, mp 236 238 ${ }^{\circ} \mathrm{C}$;

$1 \mathrm{H}$ NMR (400 MHz, $\boldsymbol{\delta}$ ppm, CDCl3): $\delta 0.85$ ppm (t, 3H, $\left.\mathrm{COOCH}_{2} \mathrm{CH}_{3}\right) ; \delta 2.1 \mathrm{ppm}\left(\mathrm{d}, 3 \mathrm{H}, \mathrm{CH}_{3}\right) ; \delta 3.85 \mathrm{ppm}(\mathrm{q}, 2 \mathrm{H}$ $\left.\mathrm{COOCH}_{2}\right) ; \delta 5.45 \mathrm{ppm}\left(\mathrm{s}, 2 \mathrm{H}, \mathrm{NH}_{2}\right) ; \delta$ 7.0-7.1 ppm $(\mathrm{m}, 5 \mathrm{H}, \mathrm{ArH}) ; \delta 7.39 \mathrm{ppm}(\mathrm{s}, 1 \mathrm{H},-\mathrm{CH})$

IR (potassium bromide): 900-675 - C-H stretching; 1097- $\mathrm{Cl}$ stretching; 1252.79- C-C=O-O stretching; 13751450- $\mathrm{CH}_{3}$ bending; 1400-1450 - $\mathrm{CH}_{2}$ bending; 1300-1600 - Ring stretching vibration; $1590.34-\mathrm{C}=\mathrm{C}$ stretching; 1719.57 $-\mathrm{C}=\mathrm{O}$ stretching; 3211.53-3415.03 - Heteroaromatic N-H stretching

Anal. Calculated for $\mathrm{C}_{17} \mathrm{H}_{16} \mathrm{ClN}_{5} \mathrm{O}_{3}: \mathrm{C}=54.63 \% ; \mathrm{H}=4.31 \% ; \mathrm{N}=18.74 \%$

Found: $\mathrm{C}=53.51 \% ; \mathrm{H}=5.21 \% ; \mathrm{N}=18.00 \%$

5-Amino-1-(5-chloro-3-methyl-1-phenyl-1H-pyrazole-4-carbonyl)-1H-pyrazole-4-carbohydrazide [6B]:This compound is obtained as colorless solid, yield $60 \%$; mp $292{ }^{\circ} \mathrm{C}$.

$1 \mathrm{H}$ NMR (400 MHz, $\boldsymbol{\delta}$ ppm, DMSO): $\delta 2.5 \mathrm{ppm}\left(\mathrm{s}, 3 \mathrm{H}, \mathrm{CH}_{3}\right) ; \delta 4.5 \mathrm{ppm}\left(\mathrm{s}, 2 \mathrm{H}, \mathrm{CONHNH}_{2}\right) ; \delta 5.5 \mathrm{ppm}$ $\left(\mathrm{s}, 2 \mathrm{H}, \mathrm{NH}_{2}\right) ; \delta$ 7.5-7.7 ppm $(\mathrm{m}, 5 \mathrm{H}, \mathrm{ArH}) ; \delta 8.15$ ppm $(\mathrm{s}, 1 \mathrm{H},-\mathrm{CH}) ; \delta 9.6 \mathrm{ppm}\left(\mathrm{s}, 1 \mathrm{H},-\mathrm{NH}, \mathrm{D}_{2} \mathrm{O}\right.$ Ex. $)$

IR (potassium bromide):706.92 $-\mathrm{C}-\mathrm{Cl}$ stretching; 1622.16 $-\mathrm{C}=\mathrm{C}$ stretching in ring; 1655.92, $1696.42-\mathrm{C}=\mathrm{O}$ stretching; 3211.53, 3285.79- $\mathrm{NH}_{2}$ stretching; 3432.39 - $\mathrm{NH}$ stretching

Anal. Calculated For $\mathrm{C}_{15} \mathrm{H}_{14} \mathrm{ClN}_{7} \mathrm{O}_{2}$ : $\mathrm{C}=54.41 \% ; \mathrm{H}=3.61 \% ; \mathrm{N}=15.86 \%$ 
Found: $\mathrm{C}=55.10 \% ; \mathrm{H}=4.01 \% ; \mathrm{N}=16.50 \%$

Ethyl-5-amino-1-(5-chloro-3-methyl-1-phenyl-1 $H$-pyrazole-4-carbonyl)-3-methyl-1 $H$-pyrazole-4-carboxylate [7A]:-

This compound is obtained as colorless solid (alcohol), yield 58\%; mp $228{ }^{\circ} \mathrm{C}$.

$1 \mathrm{H}$ NMR (400 MHz, $\delta$ ppm, CDCl3): $\delta 1.4 \mathrm{ppm}\left(\mathrm{t}, 3 \mathrm{H}, \mathrm{COOCH}_{2} \mathrm{CH}_{3}\right) ; \delta 2.4 \mathrm{ppm}\left(\mathrm{s}, 3 \mathrm{H}, \mathrm{CH}_{3}\right) ; \delta 2.65 \mathrm{ppm}$ $\left(\mathrm{s}, 3 \mathrm{H}, \mathrm{CH}_{3}\right) ; \delta 4.4 \mathrm{ppm}\left(\mathrm{q}, 2 \mathrm{H}, \mathrm{COOCH}_{2}\right) ; \delta 5.5 \mathrm{ppm}\left(\mathrm{b}, 2 \mathrm{H}, \mathrm{NH}_{2}\right) ; \delta$ 7.5-7.7 ppm $(\mathrm{m}, 5 \mathrm{H}, \mathrm{Ar} \mathrm{H})$

IR (potassium bromide): $1096-\mathrm{Cl}$ group stretching; $1261.47-\mathrm{C}-\mathrm{C}=\mathrm{O}-\mathrm{O}$ stretching; $1591.30-\mathrm{C}=\mathrm{C}$ stretching; 1710- $\mathrm{C}=\mathrm{O}$ stretching; 3217.32-3422.74- Heteroaromatic $\mathrm{N}-\mathrm{H}$ stretching

Anal. Calculated for $\mathrm{C}_{18} \mathrm{H}_{18} \mathrm{ClN}_{5} \mathrm{O}_{3}: \mathrm{C}=55.75 \% ; \mathrm{H}=4.68 \% ; \mathrm{N}=18.06 \%$

Found: $\mathrm{C}=55.10 \% ; \mathrm{H}=3.99 \% ; \mathrm{N}=17.65 \%$

\section{5-Amino-1-(5-chloro-3-methyl-1-phenyl-1H-pyrazole-4-carbonyl)-3-methyl-1H-pyrazole-4-carbohydrazide} [7B]:-

This compound is obtained as colorless solid, yield $60 \% ; \mathrm{mp} 285^{\circ} \mathrm{C}$.

$1 \mathrm{H}$ NMR (400 MHz, $\delta$ ppm, CDCl3): $\delta 2.55 \mathrm{ppm}\left(\mathrm{s}, 3 \mathrm{H}, \mathrm{CH}_{3}\right) ; \delta 2.7 \mathrm{ppm}\left(\mathrm{s}, 3 \mathrm{H}, \mathrm{CH}_{3}\right) ; \delta 4.1 \mathrm{ppm}(\mathrm{s}, 2 \mathrm{H},-$ $\left.\mathrm{CONHNH}_{2}\right) ; \delta 5.5 \mathrm{ppm}\left(\mathrm{s}, 2 \mathrm{H}, \mathrm{NH}_{2}\right) ; \delta 7.5 \mathrm{ppm}(\mathrm{m}, 5 \mathrm{H}, \mathrm{ArH}) ; \delta 9.55 \mathrm{ppm}\left(\mathrm{s}, 1 \mathrm{H},-\mathrm{NH}, \mathrm{D}_{2} \mathrm{O}\right.$ Ex. $)$

IR (potassium bromide): $1074.37-\mathrm{Cl}$ group stretching; $1309.69 \& 1552.72-\mathrm{C}-\mathrm{H}$ Stretching; $1605.77 \& 1639.52$

$-\mathrm{C}=\mathrm{O}$ stretching; $3062.05-$ Aromatic $\mathrm{C}-\mathrm{H}$ stretching; 3280.01- $\mathrm{NH}_{2}$ stretching

Anal. Calculated for $\mathrm{C}_{16} \mathrm{H}_{16} \mathrm{ClN}_{7} \mathrm{O}_{2}: \mathrm{C}=51.41 \% ; \mathrm{H}=4.31 \% ; \mathrm{N}=26.23 \%$.

Found: $\mathrm{C}=52.20 \% ; \mathrm{H}=4.55 \% ; \mathrm{N}=25.85 \%$

5-Amino-1-(5-chloro-3-methyl-1-phenyl-1H-pyrazole-4-carbonyl)-3-methyl-1H-pyrazole-4-carbonitrile [6C]:This compound is obtained as colorless solid, yield $50 \%$; $\mathrm{mp} 288^{\circ} \mathrm{C}$,

$1 \mathrm{H}$ NMR (400 MHz, $\delta$ ppm, CDCl3): $\delta 2.33 \mathrm{ppm}\left(\mathrm{s}, 3 \mathrm{H}, \mathrm{CH}_{3}\right) ; \delta 2.69 \mathrm{ppm}\left(\mathrm{s}, 3 \mathrm{H}, \mathrm{CH}_{3}\right) ; \delta$ 7.50-7.61 ppm $(\mathrm{m}, 5 \mathrm{H}, \mathrm{ArH}) ; \delta 10.98 \mathrm{ppm}\left(\mathrm{s}, 2 \mathrm{H}, \mathrm{NH}_{2}\right)$

IR (potassium bromide): $1598-\mathrm{C}=\mathrm{C}$ (in Ring) ( 3 bond conjugated); $1635-\mathrm{C}=\mathrm{O}$ stretching; $2222-\mathrm{CN}$

stretching; 2924.13 - aliphatic $\mathrm{C}$-H stretching; $3431.42-\mathrm{NH}_{2}$ stretching

Anal. Calculated for $\mathrm{C}_{16} \mathrm{H}_{13} \mathrm{ClN}_{6} \mathrm{O}: \mathrm{C}=56.39 \% ; \mathrm{H}=3.85 \% ; \mathrm{N}=24.66 \%$

Found: $\mathrm{C}=56.15 \% ; \mathrm{H}=3.21 \% ; \mathrm{N}=24.11 \%$

(5-Chloro-3-methyl-1-phenyl-1H-pyrazol-4-yl)(5-hydroxy-3-methyl-1 $H$-pyrazol-1-yl) methanone [6D]:This compound is obtained as colorless solid, yield $45 \% ; \mathrm{mp} 254^{\circ} \mathrm{C}$

1H NMR (400 MHz, $\delta$ ppm, CDCl3): $\delta 2.27 \mathrm{ppm}\left(\mathrm{s}, 3 \mathrm{H}, \mathrm{CH}_{3}\right) ; \delta 2.6 \mathrm{ppm}\left(\mathrm{s}, 3 \mathrm{H}, \mathrm{CH}_{3}\right) ; \delta 5.75 \mathrm{ppm}(\mathrm{s}, 1 \mathrm{H},-\mathrm{CH}) ; \delta$ 7.5-7.7 ppm( m,5H,ArH); $\delta 8.25 \mathrm{ppm}(\mathrm{s}, 1 \mathrm{H}, \mathrm{OH})$

IR (potassium bromide): $1658-\mathrm{C}=\mathrm{O}$ stretching; $1591.30-\mathrm{C}=\mathrm{C}$ (in Ring); 3320.51- $\mathrm{OH}-$ stretching

Anal. Calculated for $\mathrm{C}_{15} \mathrm{H}_{13} \mathrm{ClN}_{4} \mathrm{O}_{2}: \mathrm{C}=56.88 \% ; \mathrm{H}=4.14 \% ; \mathrm{N}=17.69 \%$

Found: $\mathrm{C}=55.92 \% ; \mathrm{H}=3.89 \% ; \mathrm{N}=18.13 \%$

\section{Herbicidal Activity Tests:-}

Inhibition of the root-growth of rape (Brassicacampestris $L$ ):-

The compounds to be tested are made into emulsions to aid dissolution. Rape seeds are soaked in distilled water for $4 \mathrm{~h}$ before being placed on a filter paper in a 6-cm Petri plate, to which $2 \mathrm{ml}$ of inhibitor solution had been added in advance. Usually, 15 seeds are used on each plate. The plate is placed in a dark room and allowed to germinate for 65 hat $28^{\circ}( \pm 1)$. The lengths of 10 rape roots selected from each plate are measured and the means are calculated. The percentage inhibition is calculated relative to controls using distilled water instead of the inhibitor solution.

Inhibition of the seedling growth of barnyard grass (Echinochloacrus-galli (L) Beauv):-

The compounds to be evaluated are made into emulsions to aid dissolution. Ten barnyard grass seeds are placed into a 50-ml cup covered with a layer of glass beads and a piece of filter paper at the bottom, to which $5 \mathrm{ml}$ of inhibitor solution had been added in advance. The cup is placed in a bright room and the seeds allowed germinating for $65 \mathrm{~h}$ at $28^{\circ}( \pm 1)$. The height of the aboveground parts of the seedlings in each cup is measured and the means calculated. The percentage inhibition is calculated relative to controls using distilled water instead of the inhibitor solution. The results of herbicidal activity listed in Table 2. 


\section{Conclusion:-}

In conclusion, a 5 number of Chloro(aminopyrazoly) ketone compounds and 1 number of Chloro(hydroxypyrazoly) ketone compound were synthesized and tested for herbicidal activity. However, only a few compounds exhibited moderate activity against rape or barnyard grass. In general, the results indicated that all the compounds possessed a certain extent inhibiting activities against the rape root growth and exhibited activities against barnyard grass, but their activities are not as good as the diketone herbicides.

\section{Acknowledgement:-}

The authors wish to thank, Mr. Sreekanth Yerra of Laxai Avanti Life Sciences Pvt.Ltd. Hyderabad, Dr.Omvir Singh of Izen Biosciences Hyderabad for NMR and IR spectra of synthesized compounds. We also thankful to Mrs. Monali Swar, (Quality Manager), TTCWMA, Navi-Mumbai for Herbicidal Activity testing of synthesized compounds.

\section{References:-}

1. Almsick, A.V., (2009): New HPPD-Inhibitors - A Proven Mode of Action as a New Hope to Solve Current Weed Problems Outlooks on Pest Management.20 (1): 27-30.

2. Konno, K., Goh, A., Miyoshi, K.,Ikeda, K. (1983): Herbicidal 4-benzoyl-5-phenacyloxy-pyrazole derivatives, composition and method.Mitsubishi Petrochemical Co., Ltd. US4406688 A.

3. Kubo, T., Ohno, M., Nagasawa, S., Kose, T.,Kawata, K. (2012): Behavior of Herbicide pyrazolynate and its Hydrolysate in paddy fields after application. Bull Environ Contam Toxicol. 89 (5):985-989.

4. Matsumoto H., (2004): Mode of action of pyrazole herbicides pyrazolate and pyrazoxyfen: HPPD inhibition by the common metabolite.Chapter in ACS Symposium Series, 892 (15): 161-171.

5. Ghag, S.P., Kamath, C.R., Dave, M.A., Martin,A.M., (2009): Synthesis and antimicrobial activity of 5-chloro3-methyl-1-phenyl-1H-pyrazole-4-carboxylic acid hydrazide and their Schiff's bases,J. Chemtracks, 11 (1),8792.

6. Vogel, A.I., (1986): Text book of Practical Organic Chemistry, IV ${ }^{\text {th }}$ ed., Longman Group Ltd., London, 882.

7. Arndt, F. (1943): Nitrosomethylurea. Organic Synthesis, Coll.(2):461

8. Trilleras, J., Quiroga, J., Cobo, J., Low, J., Glidewell, C.,(2005): 5-Chloro-3-methyl-1-phenyl-1H-pyrazole-4carbaldehyde: sheets built from C-H $\cdots \mathrm{O}$ and C-H $\cdots \pi($ arene) hydrogen bonds. Acta Cryst., 61(4):1055-1057.

9. Pawar, R., Patil, A., (1994): Studies on Vilsmeier-Haack reaction: a versatile new synthesis of 5-chloro-3methylpyrazole-4-carboxaldehyde 5-chloro-3-methyl-1-phenylpyrazole-4-carboxaldehyde and related fused heterocyclic compounds and heterocyclic Schiff's bases,Ind.J.Chem. (33B):156-158.

10. Zhang, X, L., Lu, X. H., Jiang, W. Q.(2008): Synthesis of 5-chloro-N-[[(fluorophenyl)amino]thioxomethyl]-3methyl-1-phenyl-1H-pyrazole-4-carboxamide derivatives and determination of their activity as agrochemical fungicides, Yingyong Huaxue,25(4):459-463 